\title{
Karl Polanyi, The Great Transformation, and Contemporary Capitalism
}

\author{
Brigitte Aulenbacher $\cdot$ Richard Bärnthaler $•$ Andreas Novy
}

(C) Österreichische Gesellschaft für Soziologie 2019

\section{Seventy-five years of The Great Transformation: history, presence, future}

Seventy-five years ago, in April 1944, Karl Polanyi's The Great Transformation-On the origins of our times (TGT) was published in the United States and England. Since then it has been translated into 15 languages (cf. Polanyi Levitt in this volume). Written in America during the war and under the impact of the Great Depression, TGT sought to come to terms with the collapse of the liberal civilization in a similarly embracing manner as Horkheimer's and Adorno's Dialectics of enlightenment, published as a preliminary version also in 1944 in the USA. TGT captures the specific historical constellation of the "revolutionary thirties" in which free trade, the gold standard, and liberal democracy reached an impasse, resulting in competing attempts to re-order society - attempts that ranged from socialism to fascism and from Stalin's "socialism in one country" to Roosevelt's New Deal. At that time, the repercussions of Polanyi's work remained fairly restricted, John Dewey's euphoric feedback being a notable exception (cf. Gräser in this volume).

B. Aulenbacher $(\bowtie)$

Institut für Soziologie, Abt. für Gesellschaftstheorie und Sozialanalysen, Johannes Kepler

Universität, Altenberger Str. 69, 4040 Linz, Austria

E-Mail: brigitte.aulenbacher@jku.at

R. Bärnthaler

Institute for Multi-Level Governance and Development, Wirtschaftsuniversität Wien,

Welthandelsplatz 1/D4, 1020 Vienna, Austria

E-Mail: Richard.baernthaler@univie.ac.at

A. Novy

Institute for Multi-Level Governance and Development, Wirtschaftsuniversität Wien,

Welthandelsplatz 1/D4, 1020 Vienna, Austria

E-Mail: andreas.novy@wu.ac.at 
Karl Polanyi reflected on ruptures and transformations; a topic area that lost its appeal after World War II. His contemporary John Maynard Keynes seemed to be much better suited to offer practical tools for steering capitalist market economies. Keynes' demise as the leading economist of the mid-20th century, however, began with the return of crisis and instability in the 1970s (Polanyi Levitt 2013). Although the 1970s have to be seen as the origin of a new "wave" of "marketization" (Burawoy 2015), the renaissance of Polanyi's œuvre, particularly with regard to TGT, started, as Polanyi Levitt and Mendell testify in this volume, in the 1980s.

Deepened by neoliberal globalisation from the 1990s onwards and intensified around the turn of the century due to protests against free trade and neoliberalism, it was this new politico-economic atmosphere in which Karl Polanyi was rediscovered. The foreword of Joseph Stiglitz to the new edition of TGT in 2001 indicates that the emerging world order might resemble the perished liberal civilization of the gold standard. Rodrik's (2011) notion of the "globalization paradox" further systematized the claim that hyperglobalisation, national sovereignty, and democracy cannot be obtained together. The contradictions inherent in globalisation processes stimulated debates on the specific form of contemporary countermovements (Silver and Arrighi 2003), led to concrete proposals to embed the economy to achieve inclusive prosperity (Naidu et al. 2019), and triggered more radical pleas for selective economic deglobalisation (Novy 2017).

Taking up the vivid debates on TGT (cf. Block and Somers 2014; Gemici 2008, 2015; Lacher 2007), Gareth Dale's trilogy on Polanyi delivered the much needed biographical and theoretical embedding of Polanyi's key concepts in this new area (Dale 2010, 2016a, 2016b). Over the last years, Polanyi gained influence not only in academia but also in the public debate. The critique of a culture of commodification and marketization, which has, at least since the Washington Consensus, been captured in the slogan "The world is not for sale", inspired not only analysis but also political agency. Whilst The Economist has identified Polanyi as a key inspiration for Jeremy Corbyn's type of democratic socialism, Robert Kuttner's (2017) extended review of Dale's Polanyi biography in the New York review of books popularized "the man from Red Vienna".

Since the (new round of) globalisation after 1989, new conflicts and protests have arisen and a re-ordering of society has again been put on the agenda. Karl Polanyi has become a key reference in research efforts to understand the contradictions inherent to the market economy and neoliberal globalisation. This notable renaissance of Polanyi's œuvre unites approaches of scholars from economics, sociology, and political science under at least five broad endeavours. First, by rediscovering the core motif of TGT, scholars have investigated whether we are witnessing another great transformation of capitalism today. In so doing, they seek to show in how far Polanyi's perspectives can facilitate an understanding of the last five decades' developments (Atzmüller et al. 2019; Burawoy 2015; Buğra and Ağartan 2007; Palumbo and Scott 2017). Such a re-reading of Karl Polanyi in a contemporary context particularly reflects on his analysis and interpretation of the history of capitalism as the result of a "double movement", i.e. the "movement" towards a commodification of land (nature), labour, money, and other "fictitious commodities" like knowledge (Burawoy 2015) or care (Fraser 2013) and the "countermovements" such as protec- 
tive public policies and social or labour movements that struggle against the perils of a "market society". Such references to Polanyi's core figures and arguments go along with detailed and contested revisions and actualizations (Block and Somers 2014; Burawoy 2015; Fraser 2013) as well as with discussions regarding competing approaches, particularly the Marxian analysis of capitalism (cf. Dörre in this volume; Holmes 2012; Silver 2003), Cultural Political Economy (Sum and Jessop 2013), neo-institutionalism (Aulenbacher et al. 2018), and social innovation research (Moulaert et al. 2013). Second, although or because the future is uncharted territory scholars have re-discovered Polanyian concepts in social-ecological transformation research, popularized by a report for the German government (WBGU 2011), leading to studies on new concepts of work (Barth et al. 2018) as well as a new mode of living (Brand and Wissen 2017; Luks 2019). Third, in terms of his analysis of capitalism and society, Polanyi (2001) inspires us to engage with the contradictions of economic "improvement" and sociocultural "habitation" in an emancipatory manner (Holmes 2018; Novy et al. 2019). Fourth, a "substantivist" understanding of the economy (Peck 2013) perceives it as an "instituted process" (Polanyi 1977, p. 31) with different modes of provisioning - "reciprocity", "redistribution", "exchange", and "householding". Polanyi does not restrict the analysis of capitalism to market exchange and processes of marketization. This leads to a further core motif of his œuvre: the relation between economy and society and how to put (market) economy in its place (again). Fifth and finally, Polanyian reflections on the survival of humankind under the auspices of "industrial civilization" and the "machine age" as well as his idea of "freedom in a complex society" (Polanyi 2001; Brie and Thomasberger 2018 and in this volume; Cangiani 2012; Novy 2019) might inspire debates on contemporary neoliberalism, digitalisation, and planetary boundaries.

\section{International research on, with, and after Karl Polanyi: composition of the special issue}

This special issue on "Karl Polanyi, The Great Transformation, and contemporary capitalism" unites distinguished scholars who demonstrate the vivacity of social research inspired by Polanyi's reflections and concepts. It considers the history of TGT, the international debate around Polanyi over the last decades, contemporary re-readings of his œuvre, and its application in a variety of fields of research and different disciplines. There are two major reasons for our decision to take these steps: First, seventy-five years of TGT let us look back and forward-back on the roots of Polanyian perspectives and forward to present and future research inspired by his thoughts. Second, the special issue refers to the gala event on 8 May 2018 when the International Karl Polanyi Society (IKPS, http://www.karlpolanyisociety. $\mathrm{com} /$ ) in Vienna has been founded. The contributions of this volume depict the elaborated articles of the opening speech and keynotes given and vividly discussed at the Chamber of Labour, Vienna, by a broad academic and non-academic audience. Their publication as special issue of the Österreichische Zeitschrift für Soziologie (Austrian Journal of Sociology) symbolizes the idea to bring Karl Polanyi, who has been forced to migrate in fascist times, back to Austria and to stimulate the 
academic and non-academic discussion on future societies in Europe and beyond (cf. for example Valderrama 2012). Publishing in English aims to enter the international Polanyi community and network with a special issue which may provide insights in how scholars make use of his work in 'our times'-a goal that was particularly highlighted during the foundation of the IKPS.

The special issue starts with an introduction by Kari Polanyi Levitt "On transformations: past, present and future?" in which Karl Polanyi's daughter provides a vivid and personal account of the origins of TGT and proceeds to reflect on the return of a universalizing form of capitalism at the end of the 20th century. Criticizing the term as well as the content of globalization, she dwells on the relevance of reembedding markets in democratic control and state agency. Marcus Gräser continues by "Historicizing Karl Polanyi" in a specific way. Gräser identifies two research gaps in the renewed interest in Karl Polanyi. First, there is a lack of contextualizing the production process of TGT and in embedding Polanyi in his spatio-temporal context-especially his American experiences. Second, Polanyi's approach, which keeps an eye out for a general logic in the distinctive national trajectories, can be seen as an idea-giver for global history-and for multi-level approaches, we would add. "Karl Polanyi and the global network inspired by his work" is an interview given by Marguerite Mendell, director of the Karl Polanyi Institute of Political Economy Montreal that hosts the Polanyi archive. In this interview, full of autobiographical reflections, she narrates the origin of her interest in Polanyi which dates back to the 1980s. Starting with archive research, she has discovered the relevance of applying Polanyi's critique to the consequences of four decades of "planned neoliberalism". While her own research focusses on social and solidarity economy, recent analyses are increasingly concerned with the ongoing authoritarian turn and the links between Trump and Brexit with neoliberal globalization. Polanyi's critique of the illusion of a "self-regulating market" has been complemented by his reflections on fascism.

In "Polanyi: Classical moral economist or pioneer cultural political economist?" Bob Jessop and Ngai-Ling Sum, founders of Cultural Political Economy (CPE) as a proper discipline, proceed in two steps. They describe Karl Polanyi as a classical moral economist based on a strong analytical distinction between substantivist and formal economics, which allowed Polanyi to identify a plurality of economic institutions that relate the economic and non-economic spheres. But Polanyi is, according to Jessop and Sum, also a precursor to cultural political economy. Although he neither applied critical discourse analysis nor critical political economy in a strict sense, he dwells in an innovative and intuitive way on key concerns of a critical semiotic institutionalism, e.g. in his analysis of economic liberalism as a faith. At the same time, Polanyi has substantially enriched critical political economy by introducing modes of provisioning beyond the market. Michael Brie und Claus Thomasberger approach a field which has so far received less attention in the renaissance of Karl Polanyi. "Karl Polanyi's Search for Freedom in a Complex Society" identifies questions of freedom as one of Polanyi's lifelong concerns. While the last chapter in TGT is dedicated to "freedom in a complex society", Polanyi has written on this issue already in the 1920s and took the issue up in the 1950s again. He criticizes the liberal notion of freedom not as wrong, but as insufficient. Besides, he was also aware of the limits of sectional interests, including class movements that did not consider the 
consequences of their decisions for society as a whole. For Polanyi, freedom and responsibility are intertwined. Overview, an understanding of societal structures, is required for free agency and decision-making to overcome fragmentation and the dominance of sectional interests.

Maria Markantonatou uses Polanyi's analysis of the conservative 1920s to understand contemporary Greece. In "Conservative 1920s" and conservative 2010s? Austerity politics in interwar Austria and present-day Greece, she compares these two "test cases". The League of Nations in the 1920s and the Troika in the 2010s applied similar policy instruments by means of a deliberately interventionist political method, leading to comparable policy outcomes in different historical contexts. Markantonatou uses the empirical analysis to show the power of Polanyi's concept of "authoritarian interventionism" in grasping the contradictory agency of liberal actors then and now. Sabine Frerichs reminds us that, although Polanyi had a doctoral degree in law, he gave astonishingly little attention to the role of law as both a commodifier and a decommodifier. In "Karl Polanyi and the law of market society" Frerichs dwells on this underdeveloped research field by relating Polanyi's work to Marxist scholarship, more concretely Evgeny Pashukanis, and American institutionalism, especially John Rogers Commons. Law is decisive for commodification processes by guaranteeing property rights and contractual security, but in neoliberalism there even emerge "law markets" that permit shopping for the best legal framework for economic interactions. Frerichs eloquently exposes a dichotomous picture of two types of law that contain antagonistic rationalities and have the potential to counteract each other within the same political-economic system: "law as a commodity" that serves private interests and "law as an institution" that promotes public interest. Therefore, law can be market constraining, protective social legislation as well as market enabling, private, and international law. Ernst Langthaler and Elke Schüßler undertake a comparative analysis in two sectors, dealing with the "fictitious commodities" labour and land. In "Commodity Studies with Polanyi: Disembedding and Re-Embedding Labour and Land in Contemporary Capitalism" they enrich the study of commodity chains by analysing industrial relations in the garment industry and study the impact of the feed-livestock-meat complex on land, its ownership structure, land use, and uneven global development. Concluding, they tentatively put forward the argument that a "real" countermovement would probably have to find ways to re-embed land, labour, and money jointly, as all three are interlinked in driving the dynamics of contemporary commodity chains. Klaus Dörre examines the worldviews of employees with right-wing sympathies in German industrial and service enterprises. In "Take Back Control! Marx, Polanyi and Right-Wing Populist Revolt" he interprets interviews with right-leaning employees to grasp the relationship between contemporary market radicalism and authoritarian countermovements, currently institutionalized in Germany's AfD. In line with Burawoy, Dörre distinguishes between market-critical and class movements, the first denominated Polanyian and the second Marxist. He shows how the Polanyian and Marxist ideal types are entangled in right-wing populist movements that emerge from inequalities as well as alienation due to increased competition. They demand a protective nation state to (re-)constitute a national community, but, by embracing 
core capitalist objectives of expansionism, they undermine their potential to take back control, which is at centre stage of their anti-systemic political stances.

The special issue also includes reviews on four recently published books that show the vivid discussions to conceptualize the re-ordering of contemporary societies inspired by Polanyi. Fabienne Décieux and Christian Leitner engage with Tim Rogan's “The Moral Economists: R. H. Tawney, Karl Polanyi, E. P. Thompson, and the Critique of Capitalism" (2017), which not only explicates Tawney, Polanyi, and Thompson as constitutive for a moral economy approach in 20th century England, but also provides an intellectual history of these three moral economists and interconnects them in an innovative way. Since questions of morality have gained importance in the face of multiple crises, the book seems to have been published just at the right time. Karl Beyer reviews Antonio Palumbo's and Alan Scott's "Remaking Market Society: A Critique of Social Theory and Political Economy in Neoliberal Times" (2017) in which the authors seek to formulate a powerful modernist counternarrative to both postmodern social theory and neoliberal political economy approaches towards social and economic change. For Beyer, the great merit of the book is its well-elaborated analytical framework for examining processes of implementing market rules within the public sector through New-Public-Management techniques. In so doing, the authors demonstrate the usefulness of a Polanyian political approach to analyze contemporary neo-liberalism. Christopher Holmes' "Polanyi in Times of Populism-Vision and Contradiction in the History of Economic Ideas" (2018) takes a different approach by placing Polanyi in a postmodern tradition. Holmes interprets the TGT as aiming at uncovering systems of thought that seek to transcend the contradictions between economic "improvements" and sociocultural "habitation" into one abstract vision. However, as Polanyi noticed, people in a market society need both means for habitation and opportunities for improvement. Political decisions are, therefore, unavoidable. In his review, Richard Bärnthaler considers Holmes' approach highly productive, both analytically as well as with regards to its practical consequences. It is a much-needed plea to recognise that the democratic precondition for any exploratory movement and learning process, which are so vital in times of transformation, is a society in which plural-and often incommensurable-interests, ideas, and values can be expressed and discussed. Finally, Christoph Deutschmann discusses "Karl Polanyi's Vision of a Socialist Transformation" (2018), edited by Michael Brie and Claus Thomasberger 2018. The book, compiled by fifteen outstanding scholars from Europe, North America, and Asia, represents an impressive effort to clarify the ambiguities in Polanyi's theoretical conceptualization and political and philosophical understanding of socialism. Although Deutschmann highlights that the book does not provide the reader with a red thread across Polanyi's writings and ideas, it is nevertheless the best contemporary attempt to seriously engage with the contradictions, paradoxes, and unfinished thoughts in Polanyi's work. 


\section{Conclusion of the special issue: re-discovering and re-reading Karl Polanyi for today}

Whilst, in some respects, Polanyi arguably lacked some theoretical clarity and empirical depth (e.g. in his ambivalent depiction of laissez-faire in TGT), other criticism towards his work may have, at least partly, resulted from a historically institutionalized disciplinary blindness. Polanyi has often been conceived as too sociological for historians, too historical for economists, or too political for an academic (cf. Gräser in this volume). His approach has been-and, to some extent, still is-unconventional. Polanyi transgressed not only traditional disciplinary but also academic boundaries, deliberately moving between disciplines and engaging with extra-scientific actors (such as during his work for the Worker's Educational Association in England, which laid the foundation for TGT). Polanyi did not provide us with a concrete methodological or methodical toolkit. Neither is his epistemology uncontested (cf. Holmes, who considers Polanyi a postmodern versus Palumbo and Scott, who place him in a modern tradition) or rigid. Instead, Polanyi offers a powerful heuristic to make sense of the heterogeneous and often contradictory societal developments in times of rupture and transformation-the interconnected nature of these developments does not respect traditional boundaries. Taking all this into account, Polanyi may have pointed the way ahead towards what today is known as transdisciplinary research.

He inspired not only important theoretical discussions (cf. Jessop and Sum; Brie and Thomasberger in this volume), but also a broad variety of empirical studies that apply different methodical tools (cf. Markantonatou; Langthaler and Schüßler; Dörre in this volume) to understand contemporary socio-economic, social-ecological, and socio-technical developments as well as their interrelations. The Polanyian framework, thus, is conducive to bringing together scholars from varying disciplinary backgrounds in productive ways. Such interaction seems vital to face the interlinked challenges of the 21 st century. We can, however, not stop here. The challenge ahead of us will be to integrate extra-scientific actors into processes of knowledge production, thus, breaking down the all too artificial boundaries between science, policy, and society. Polanyi has not only been a role model in practice, but his flexible framework and often pragmatic stances allow to integrate not only different methods, methodologies, and epistemologies, but also different forms of knowledge.

Only through increased interaction among heterogeneous actors (both academic and extra-scientific) will it be possible to create new narratives, forms of sensemaking, and imaginaries democratically that lead us into a new transformation that does not proceed by disaster, but by design. The specific form of such transformation is contingent, open-ended, and needs to be shaped through experimentation. The IKPS aims to contribute to creating one of the many spaces which we need to rethink society and to transform capitalism in a way that humankind may survive industrial civilization of the last centuries and market-fundamentalism of the last decades. May the special issue be an inspiring contribution to such a debate. 


\section{References}

Atzmüller, Roland, et al. 2019. Capitalism in transformation. Movements and countermovements in the 21st Century. Cheltenham: Edward Elgar.

Aulenbacher, Brigitte, Fabienne Décieux, and Birgit Riegraf. 2018. Capitalism goes care. Elder and child care between market, state, profession, and family and questions of justice and inequality. Equality, Diversity and Inclusion 37(4):347-360.

Barth, Thomas, Georg Jochum, and Beate Littig. 2018. Nachhaltige Arbeit - die sozial-ökologische Transformation der Arbeitsgesellschaft befördern. GAIA - Ecological Perspectives for Science and Society 27(1):127-131.

Block, Fred, and Margaret Somers. 2014. The power of market fundamentalism. Karl Polanyi's critique. Cambridge: Harvard University Press.

Brand, Ulrich, and Markus Wissen. 2017. Imperiale Lebensweise. Zur Ausbeutung von Mensch und Natur im globalen Kapitalismus. München: oekom.

Brie, Michael, and Claus Thomasberger. 2018. Karl Polanyi's vision of socialist transformation. Montreal: Black Rose Books.

Burawoy, Michael. 2015. Facing an unequal world. Current Sociology 63(1):5-34.

Buğra, Ayşe, and Kaan Ağartan. 2007. Reading Karl Polanyi for the twenty-first century: market economy as a political project. New York: Palgrave Macmillan.

Cangiani, Michele. 2012. Freedom in a complex society. International Journal of Political Economy 41(4):34-53.

Dale, Gareth. 2010. Karl Polanyi: The limits of the market. Cambridge: Polity Press.

Dale, Gareth. 2016a. Karl Polanyi. A life on the left. New York: Columbia University Press.

Dale, Gareth. 2016b. Reconstructing Karl Polanyi. Excavation and critique. London: Pluto.

Fraser, Nancy. 2013. A triple movement? Parsing the politics of crisis after Polanyi. New Left Review 81:119-132.

Gemici, Kurtuluş. 2008. Karl Polanyi and the antinomies of embeddedness. Socio-Economic Review $6(1): 5-33$

Gemici, Kurtuluş. 2015. The neoclassical origins of Polanyi's self-regulating market. Sociological Theory 33(2):125-147.

Holmes, Christopher. 2012. Problems and opportunities in Polanyian analysis today. Economy and Society 41(3):468-484

Holmes, Christopher. 2018. Polanyi in times of populism: vision and contradiction in the history of economic ideas. London: Routledge.

Kuttner, Robert. 2017. The man from Red Vienna. https://www.nybooks.com/articles/2017/12/21/karlpolanyi-man-from-red-vienna/. Accessed 25 Feb 2019.

Lacher, Hannes. 2007. The slight transformation: contesting the legacy of Karl Polanyi. In Reading Karl Polanyi for the twenty-first century: market economy as a political project, 49-64. New York: Palgrave Macmillan.

Luks, Fred (ed.). 2019. Chancen und Grenzen der Nachhaltigkeitstransformation: Ökonomische und Soziologische Perspektiven. Berlin: Springer.

Moulaert, Frank, Diana MacCallum, Abid Mehmood, and Abdelillah Hamdouch (eds.). 2013. The international handbook of social innovation. Collective action, social learning and transdisciplinary research. Cheltenham: Edward Elgar.

Naidu, Suresh, Dani Rodrik, and Gabriel Zucman. 2019. Economics for inclusive prosperity: an introduction. In Economics for inclusive prosperity: an introduction, ed. Economics for Inclusive Prosperity (EfiP) network, 1-9. https://econfip.org/wp-content/uploads/2019/02/Economics-for-InclusiveProsperity.pdf. Accessed 25 Feb 2019.

Novy, Andreas. 2017. Emancipatory economic deglobalisation: A Polanyian perspective I Desglobalização Econômica Emancipatória: Uma Perspectiva a Partir De Polanyi. Revista Brasileira De Estudos Regionais E Urbanos 19(3):554-575.

Novy, Andreas. 2019. Kritik der westlichen Lebensweise. In Chancen und Grenzen der Nachhaltigkeitstransformation. Ökonomische und soziologische Perspektiven, ed. F. Luks, 43-58. Berlin: Springer Gabler.

Novy, Andreas, Richard Bärnthaler, and Basil Stadelmann. 2019. Navigating between improvement and habitation: countermovements in housing and urban infrastructure in Vienna. In Capitalism in transformation. Movements and countermovements in the 21st Century, ed. R. Atzmüller, B. Aulenbacher, U. Brand, F. Décieux, K. Fischer and B. Sauer. Cheltenham: Edward Elgar. 
Palumbo, Antonino, and Alan Scott. 2017. Remaking market society: a critique of social theory and political economy in neoliberal times. Abingdon, Oxon, New York: Taylor \& Francis.

Peck, Jamie. 2013. Disembedding Polanyi: exploring Polanyian economic geographies. Environment and Planning A 45(7):1536-1544.

Polanyi, Karl. 1977. The livelihood of man. New York: Academic Press.

Polanyi, Karl. 2001. The Great Transformation: the political and economic origins of our time, 2 nd edn., Boston: Beacon Press.

Polanyi Levitt, Kari. 2013. From the great transformation to the great financialisation. On Karl Polanyi and other essays. Halifax, Winnipeg: Fernwood.

Rodrik, Dani. 2011. The globalization paradox. New York: Norton.

Rogan, Tim. 2017. The moral economists: R. H. Tawney, Karl Polanyi, E. P. Thompson, and the critique of capitalism. Princeton: Princeton University Press.

Silver, Beverly J. 2003. Forces of labor. Workers' movements and globalization since 1870. Cambridge: Cambridge University Press.

Silver, Beverly J., and Giovanni Arrighi. 2003. Polanyi's "double movement": the Belle Epoques of British and U.S. hegemony compared. Politics \& Society 31(2):325-355.

Sum, Ngai-Ling, and Bob Jessop. 2013. Towards a cultural political economy: putting culture in its place in political economy. Cheltenham: Edward Elgar Publishing.

Valderrama, Paula. 2012. Planning for freedom. International Journal of Political Economy 41(4):88-105.

WBGU. 2011. Hauptgutachten. Welt im Wandel: Gesellschaftsvertrag für eine große Transformation. Berlin: Wissenschaftlicher Beirat der Bundesregierung Globale Umweltveränderungen (WBGU). https://www.wbgu.de/fileadmin/user_upload/wbgu.de/templates/dateien/veroeffentlichungen/ hauptgutachten/jg2011/wbgu_jg2011.pdf. Accessed 25 Feb 2019.

Brigitte Aulenbacher is Professor of Sociological Theory and Social Analysis, heads the Department for the Theory of Society and Social Analyses at the Institute of Sociology at the Johannes Kepler University Linz/Austria. She is vice-president of the International Karl Polanyi Society and co-edits (with Klaus Dörre) Global Dialogue - the Magazine of the International Sociological Association ISA.

Richard Bärnthaler works at the Institute for Multi-Level Governance and Development (Vienna University of Economics and Business) and at the Department of Development Studies (University of Vienna) on topics concerning science studies (resp. STS), philosophy of science, transdisciplinarity, and urban studies. Most recent publication: Navigating between improvement and habitation: Counter-Movements in housing and urban infrastructure in Vienna (fc. 2019, Edward Elgar; with A. Novy \& B. Stadelmann).

Andreas Novy is a socioeconomist, associate professor at and head of the Institute for Multi-Level Governance and Development (MLGD) at Vienna University of Economics and Business. He has published extensively in the field of urban development, social innovation and transdisciplinarity. He is president of the International Karl Polanyi Society, hosted at MLGD. 